\title{
Serum Gonadotrophin
}

\section{FURTHER PURIFICATION OF THE ACTIVE MATERIAL}

\author{
By C. RIMINGTON AND I. W. ROWLANDS, National Institute for Medical Research, \\ Hampstead, London, N.W. 3
}

(Received 16 December 1943)

In Part 1 of this series, Rimington \& Rowlands (1941) described the preparation from pregnant mares' serum, by processes suitable for large-scale operation, of a stable active concentrate having a gonadotrophic potency of 150-625 i.u./mg. depending upon the activity of the crude serum, and in a yield representing $73 \%$ of the total activity originally present. The method entailed the following stages: $(a)$ removal of the bulk of the serum proteins by metaphosphoric acid; (b) adsorption of the active material from the filtrate upon benzoic acid followed by removal of the latter with acetone; (c) dissolution of the adsorbate (termed the 'initial powder') in dilute alkali and then fractionation with ethanol at $\mathrm{pH} 4 \cdot 8$.

The material we obtained pas a white powder easily soluble in water and containing $2.5-3.5 \%$ of carbohydrate, determined as hexose by the orcinol method. It has been found suitable for veterinary practice.

We now present work carried out with the object of obtaining gonadotrophin preparations of the highest possible purity for study of their chemical properties and for possible use in human medicine. We have thus obtained material assaying 12,500 i.u./mg. (Rimington \& Rowlands, 1943). The starting-point of our studies has been the stable concentrate described in our first paper, but we have also made some improvements in the process there described which result in speedier working and a more potent product (200-1000 i.u./mg.).

\section{Summary of the improved process}

The following is a summary of our modified procedure:

(1) The serum is diluted with an equal volume of water.

(2) $0.3 \mathrm{~N}-\mathrm{HPO}_{3}$ is added as previously described until pH about 3.6 is reached (test by Congo red with a buffer solution as control); $0.01 \mathrm{~N}-\mathrm{HPO}_{3}$ washing of the precipitate is carried out as previously jescribed.

(3) Precipitation of benzoic acid is carried out as previously described. Test end-point, pH 4.6, with brom-cresol-green indicator with buffer as control.
(4) Add acetone to precipitate in proportion of 1.5 vol. to 1 vol. of original serum. The solid should settle rapidly.

(5) After collection, wash precipitate once with $80 \%$ aqueous acetone to remove inorganic materials, salts, etc.

(6) Dissolve precipitate while still moist by adding water and alkali in following proportions: For each 11 . of original serum mix $190 \mathrm{ml}$. water and $10 \mathrm{ml} . \mathrm{N}-\mathrm{NaOH}$ and add to the precipitate. Stir mechanically and, if necessary, add further $\mathrm{N}-\mathrm{NaOH}$ drop by drop to adjust to $\mathrm{pH} 7 \cdot 0$. This operation takes 2-3 hr.

(7) Measure volume of this solution of the material designated previously (Rimington \& Row. lands, 1941) 'Initial powder' which is usually turbid or strongly opalescent. For each $540 \mathrm{ml}$. add $500 \mathrm{ml}$. of ethanol. Stir mechanically and add $5 \%$ acetic acid in $50 \%(\mathrm{v} / \mathrm{v})$ ethanol until $\mathrm{pH}$ is $4 \cdot 7-4 \cdot 8$. Test end-point by adding a drop to about $1.5 \mathrm{ml}$. of water in a test-tube, then a drop of brom-cresolgreen, and comparing colour with a drop of $50 \%$ ethanol containing buffer $\mathrm{pH} 4.8$ similarly diluted and treated.

(8) Centrifuge for about $30 \mathrm{~min}$. to collect precipitate. If material deposits slowly, some of the buffered $50 \%$ ethanol may be added to assist flocculation. Shake precipitate for a few minutes with about three times its bulk of buffered $50 \%$ ethanol, and centrifuge (see (10)). Combine supernatant with main liquid. Add 0.5 vol. of ethanol to bring to $66 \%(\mathrm{v} / \mathrm{v})$ and chill overnight.

(9) Collect on centrifuge, wash once each by absolute ethanol, acetone, and ether, and dry in vacuo.

(10) The precipitate (see (8)) may be further washed by three successive shakings with buffered $50 \%$ ethanol, each shaking (mechanical) lasting about $30 \mathrm{~min}$. These combined washings, when brought to $66 \%(v / v)$ ethanol content, yield a further small proportion of original activity, but the potency of the material is lower, being in general only one-tenth of that of the product obtained from the main alcoholic liquor plus first washing. Products should be kept dry over $\mathrm{CaCl}_{2}$. 


\section{Results with the improved process}

In working up 25 large batches of serum, from individual pregnant mares, we again encountered much variation in the over-all yield of gonadotrophin obtained by the above procedure. Where lower yields were encountered, losses could almost invariably be traced to unsatisfactory adsorption on the benzoic acid. The metaphosphoric acid precipitation gives an almost quantitative return in the filtrate, and the performance of the ethanol fractionation in a large number of experiments has been uniformly good, affording on the average a yield at stage 9 of $70 \%$ of the activity of the original serum and, in addition, as the result of carrying out stage 10, a further $7 \%$.
It will be noticed from Table 1 that the average yield in the ' $B$ ' fraction, $76 \%$, is not so high as that reported, in our first paper, as a result of applying the procedure to much smaller quantities of material. We have already drawn attention to the fact that potency and carbohydrate content run in opposite directions during this stage (' $B$ ' fractions 2.5-4.0\%; ' $A$ ' fractions $8.0-8.5 \%$ ) and it is also noticeable, from Table 1 , that there is a positive correlation between the potencies of the initial powders and the potencies of the products obtained from them.

Repetition of the process of dissolving the material in the requisite quantity of alkali, adding ethanol to $50 \%$ and then titrating to $\mathrm{pH} 4.8$ by alcoholic acetic acid, failed to produce any substantial further purification. It was discovered however, that when the dry material was shaken

Table 1. Purification of 'initial powders' by adjustment of $50 \%$ alcoholic solutions to $\mathrm{pH} 4 \cdot 8$

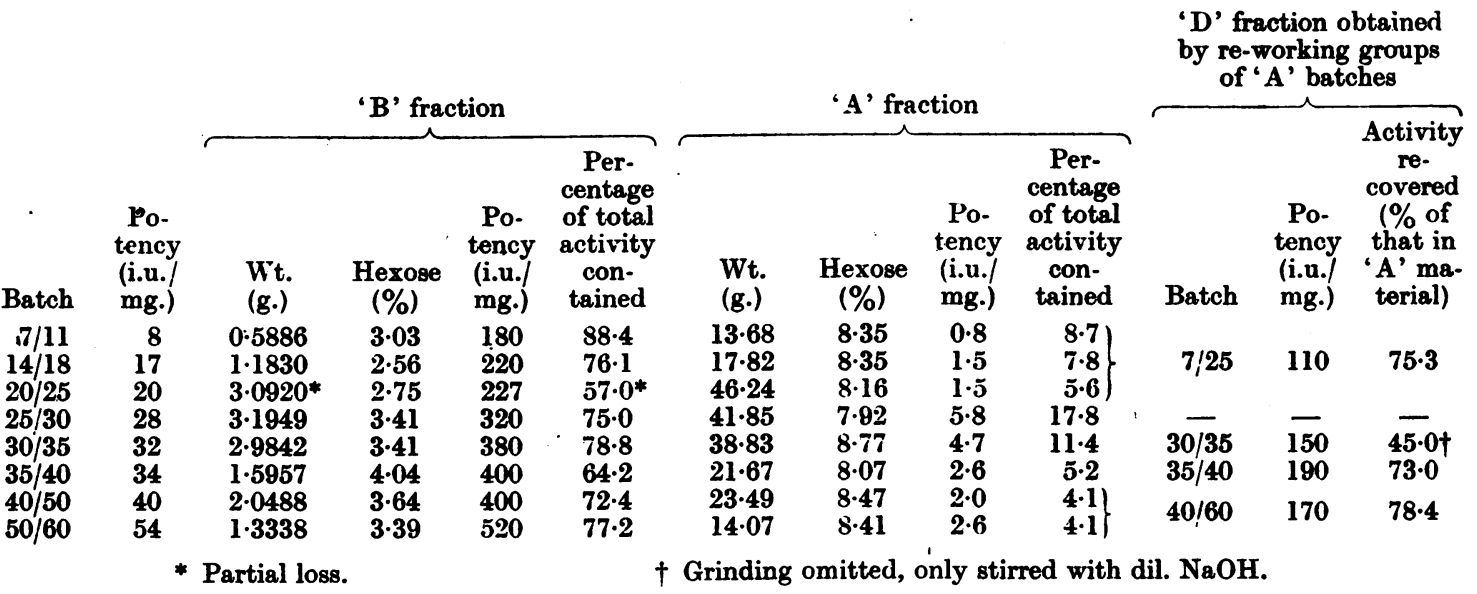

Table 1 summarizes the results of ethanol purification applied to dry initial powders from an earlier collection and grouped according to potency. The manipulation of batch $25 / 30$ (wt. $48.7 \mathrm{~g}$.) is described in illustration.

The pooled material was passed through a no. 40 mesh sieve and ground in a mortar with 21 . of water containing $21.5 \mathrm{ml}$. of $\mathrm{N}-\mathrm{NaOH}$, the suspension being stirred mechanically overnight at $0^{\circ}$. 21 . of absolute ethanol were then added and, whilst being stirred, $52 \mathrm{ml}$. of alcoholic acetic acid $(5 \%$ acetic acid in $50 \%(v / v)$ ethanol) added drop by drop to the chilled solution. This brought the $\mathrm{pH}$ to $4 \cdot 8$. The precipitate was separated on the centrifuge, washed with buffered $50 \%$ ethanol (pH 4.8), and the supernatant fluid together with washings made up to $66 \%(v / v)$ ethanol. After maintenance at $0^{\circ}$ overnight, the solution was centrifuged and the precipitate (' $B$ ' fraction) dehydrated with acetone and ether, dried and assayed. The bulky residue of material (' $A$ ' fraction), precipitated by the addition of the alcoholic acetic acid to $\mathrm{pH} 4.8$, was similarly dehydrated and assayed, after which it was subjected to a repetition of the whole process, yielding an active ' $D$ ' fraction and a virtually inert residue, ' $C$ '. with about 10 times its quantity of $50 \%$ ethanol

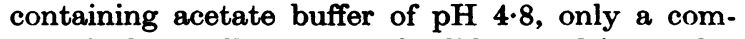
paratively small amount of solid passed into solution, but this carried by far the greater proportion of the activity ( $80 \%$ or more); hence a substantial increase in potency was effected. Provided the solid had been well sieved, a single extraction for $0.5-1 \mathrm{hr}$. on the shaking machine was adequate-second and third shakings only dissolved further material of lower potency-but as the insoluble residue does not pack down well in the centrifuge, it should be stirred with a liberal washing of buffered $50 \%$ ethanol and again centrifuged to avoid undue loss of activity. The combined extract and washing, when adjusted to $66 \%(\mathrm{v} / \mathrm{v})$ of ethanol and chilled overnight, deposits a precipitate having about 10 times the potency of the starting material. Table 2 illustrates these points.

A concentration of $66 \%(v / v)$ ethanol was found sufficient to precipitate the active material; at $75 \%$ concentration additional impurities were brought down, leading to a product of lower potency. 
Table 2. Purification of $32 \mathrm{Bf}$ by serial shakings with $50 \%(\mathrm{v} / \mathrm{v})$ ethanol buffered at $\mathrm{pH} 4.8$

Potency

(i.u./mg.)

Starting material

One shaking for $30 \mathrm{~min}$. with buffered

ethanol + one washing; material pre. cipitated by $66 \%(v / v)$ ethanol

Second shaking as above

Residual material

2400

100

48

\section{Effect of $\mathrm{pH}$ upon yield and potency of material precipitated by $66 \%(\mathrm{v} / \mathrm{v})$ ethanol}

Fractionation between $\mathrm{pH}$ 7.0 and 3.5. We explored the relations between $\mathrm{pH}$ at which ethanol precipitation was effected and the yield and potency of the product. No sharp optimum $\mathrm{pH}$ was discovered, but it was observed that at $\mathrm{pH}$ values greater than 6 very little, if any, precipitation of active material occurs, and that below $\mathrm{pH} 4 \cdot 5-4 \cdot 8$, the lower the $\mathrm{pH}$ the less impurity accompanies the active material in the precipitate, leading to a steadily increasing potency. Good use of this observation was made at a later stage, but we first concentrated upon eliminating as much as possible at the $\mathrm{pH}$ region higher than 6 . The results of two typical experiments upon different starting materials are reproduced in Tables 3 and 4, illustrating the use of acetate and phthalate buffers respectively.

Table 3. Fractionation by $66 \%$ (v/v) ethanol at different $\mathrm{pH}$ values, with acetate buffers

Starting material 480 i.u./mg. $4 \mathrm{ml}$. stock solution contains $30 \mathrm{mg}$.

\begin{tabular}{lccc} 
30 mg. & \multicolumn{3}{c}{ Precipitate } \\
pH & $\begin{array}{c}\text { Total } \\
\text { Wt. } \\
(\mathbf{m g .})\end{array}$ & $\begin{array}{c}\text { Potency } \\
\text { (i.u./mg.) }\end{array}$ & $\begin{array}{c}\text { activity } \\
(\%)\end{array}$ \\
4.0 & 15.5 & 930 & 100 \\
4.5 & 22.1 & 643 & 98 \\
5.0 & 28.0 & 500 & 97 \\
6.0 & 24.2 & 562 & 94 \\
7.0 & 17.0 & 138 & 16 \\
: no buffer & 8.4 & 12.5 & 7
\end{tabular}

Table 4. Fractionation by $66 \%$ (v/v) ethanol at different $\mathrm{pH}$ values, with phthalate buffers

Starting material 1000 i.u./mg. 4 ml. stock solution contains $11.5 \mathrm{mg}$.

\begin{tabular}{|c|c|c|c|}
\hline \multirow[t]{2}{*}{ 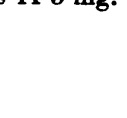 } & \multicolumn{3}{|c|}{ Precipitate } \\
\hline & $\begin{array}{l}\text { Wt. } \\
\text { (mg.) }\end{array}$ & $\begin{array}{c}\text { Potency } \\
\text { (i.u./mg.) }\end{array}$ & $\begin{array}{c}\text { Total } \\
\text { activity } \\
(\%)\end{array}$ \\
\hline $\begin{array}{l}\mathbf{3} \cdot \mathbf{5} \\
\mathbf{4} \cdot \mathbf{0} \\
\mathbf{4} \cdot \mathbf{5} \\
\mathbf{5} \cdot \mathbf{0} \\
\mathbf{5 \cdot 5} \\
\mathbf{6 \cdot 0} \\
\mathbf{6 \cdot 5}\end{array}$ & $\begin{array}{l}4 \cdot 11 \\
5 \cdot 82 \\
7.22 \\
7 \cdot 36 \\
2 \cdot 49 \\
2 \cdot 23 \\
3 \cdot 46\end{array}$ & $\begin{array}{r}2310 \\
1630 \\
1560 \\
1320 \\
440 \\
450 \\
\text { Nil }\end{array}$ & $\begin{array}{r}83 \\
83 \\
98 \\
85 \\
10 \\
9 \\
0\end{array}$ \\
\hline
\end{tabular}

Each experiment was performed as follows: Into each of a series, of $15 \mathrm{ml}$. centrifuge tubes were measured $4 \mathrm{ml}$. of a stock solution of the starting material, then $1 \mathrm{ml}$. of M buffer (for $\mathrm{pH} 7.0$ a phosphate buffer was used) and $10 \mathrm{ml}$. of ethanol. The mixtures were left at $0^{\circ}$ for $2 \mathrm{hr}$., centrifuged and the precipitates redissolved in $4 \mathrm{ml}$. of water for assay and dry-weight determination.

It was noticed that the precipitates forming at $\mathrm{pH}$ 6-7 consisted almost entirely of crystalline inorganic metaphosphates which, after several recrystallizations, became completely inactive. At the lower $\mathrm{pH}$ 's this material is also precipitated, together with proteins carrying gonadotrophic activity, but under these conditions it forms a viscous liquid phase. The best condition for its elimination without loss of gonadotrophic activity was found to be precipitation at $56 \%(\mathrm{v} / \mathrm{v})$ ethanol concentration from a solution buffered at $\mathrm{pH} 6.5$ (acetate buffer). This stage is included in the example given below of the purification of a large batch (P.M.S. 38) of accumulated material, assaying 134 i.u./mg., hexose content $2 \cdot 2 \%$, which had been treated as far as the titration in $50 \%(v / v)$ ethanol by acetic acid to $\mathrm{pH} \mathrm{4.8.} \mathrm{The} \mathrm{description} \mathrm{illustrates} \mathrm{our} \mathrm{working} \mathrm{pro-}$ cedure developed as a result of the various experiments set forth above.

$20 \mathrm{~g}$. of the sieved powder (40 mesh) were shaken on a machine for $1.5 \mathrm{hr}$. with $200 \mathrm{ml}$. of $50 \%(\mathrm{v} / \mathrm{v})$ ethanol containing acetate buffer $\mathrm{pH} \mathrm{4.8}$. After chilling for $2 \mathrm{hr}$., the insoluble material was separated on the centrifuge and washed by stirring with $30 \mathrm{ml}$. of buffered $50 \%(v / v)$ ethanol and re-centrifuged. The main supernatant and washings were combined, ethanol added to $66 \%(v / v)$ and the mixture left at $0^{\circ}$ overnight. The precipitate was collected on the centrifuge and redissolved in $100 \mathrm{ml}$. water. Assay showed that this solution contained $75 \%$ of the total starting activity and $\mathbf{1 . 3} \mathrm{g}$. of dry matter; the potency had thus been raised 12 times to $1530 \mathrm{i}$.u./mg. The potency of the rejected material, insoluble in the $50 \%$ ethanol, was 35 i.u./mg.

To the remainder of the $100 \mathrm{ml}$. of solution were added $10 \mathrm{ml}$. of $\mathrm{M}$-acetate buffer of $\mathrm{pH} 6.5$ and $140 \mathrm{ml}$. of ethanol, i.e. $56 \%(v / v)$. On stirring the opalescent mixture for a few minutes, crystals commenced to separate; it was left at $0^{\circ}$ overnight. The crystals (wt. 0.3006 g., activity 37 i.u./mg.) were separated on the centrifuge and the clear supernatant fluid acidified to $\mathrm{pH} 4.0$ with acetic acid, then ethanol added to make $66 \%(v / v)$ concentration. After chilling at $0^{\circ}$ overnight, the precipitate was collected on the centrifuge, dehydrated with acetone and ether and dried in vacuo. The product, $38 \mathrm{E}$, was analyzed with the following results:

$\begin{array}{ll}\text { Weight } & \mathbf{0 . 6 2 5} \mathrm{g} . \\ \text { Hexose content } & 11.4 \% \\ \text { Potency } & 3000 \mathrm{i} . \mathrm{u} . / \mathrm{mg} . \\ \text { Total activity } & \mathbf{7 0} \%\end{array}$

Fractionation between pH 3.5 and 1.5. In dis. cussion of the data presented in Tables 3 and 4, it has been pointed out that the lower the pH at which the fractionation by ethanol was carried out. the greater the potency of the resulting product. It was clearly desirable to extend this investigation to $\mathrm{pH}$ regions lower than 3.5 , but the reported lability of the gonadotrophic hormone in acid solutions would, we felt, render difficult the interpre- 
tation of results. By adopting a balance-sheet type of experiment, however, and keeping the temperature at $0^{\circ}$ throughout by immersion of all reaction vessels in melting ice, we have been able to extend our observations to pH $\mathbf{1 . 5}$ and to show that up to this point the relation still holds good-the lower the $\mathrm{pH}$, the higher the potency of the product obtained.

From solutions more acid than $\mathrm{pH} 1 \cdot 5$, in which buffering is very difficult and inadequate, precipitation does not readily occur and fractionation consequently fails: $\mathrm{pH} 1.5$ represents the practicable limit for these experiments. That the action involved is not one of cleavage or hydrolytic fission of a large molecule, leaving an ever smaller active

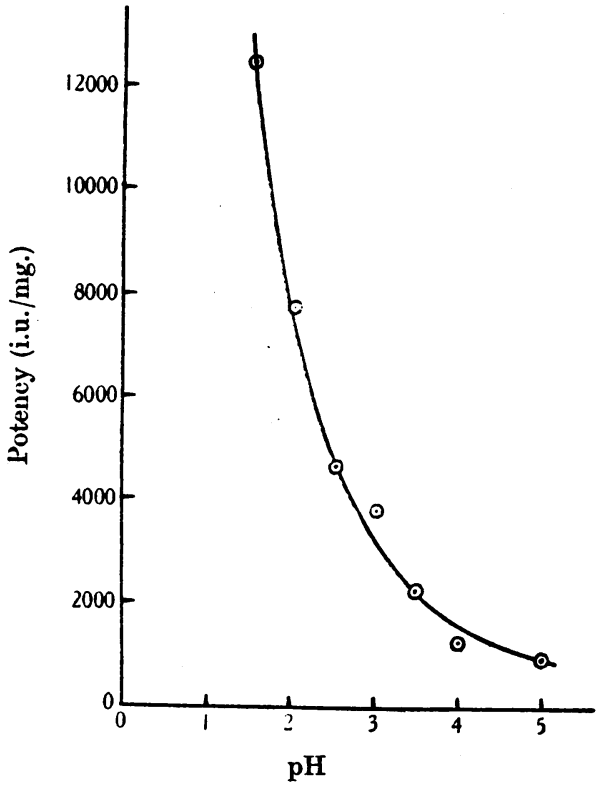

Fig. 1. Relationship between $\mathrm{pH}$ and potency of product in fractionation of serum gonadotrophin by ethanol.

moiety resembling a prosthetic group, we presume to have established as the result of an experiment, carried out at pH $2 \cdot 5$, in which it was shown.that the activity of the final product was independent of the time of contact with acid solution. Rather must the purification be compared with the dissociation of components one from another like those of a salt, unless, of course, the view be taken that at the $\mathrm{pH}$ employed the impurities in our mixture remain in solution as acid-metaprotein compounds, whilst the fraction or fractions carrying the gonadotrophic activity do not form such compounds, or have unusually acid isoelectric points. The presence of buffer salts seems to be essential for the precipitations in $\tilde{50}$ and $66 \%(v / v)$ ethanol. In preliminary experiments the mixtures were shaken mechanically with small quantities of chloroform, according to the technique of Sevag (1934), but the results obtained were similar in the absence or presence of chloroform and its addition was, therefore, discontinued.

Two preparations were used in the experiments, viz. P.M.S. 38 R with potency 650 i.u. $\mathrm{mg}$., of which $100 \mathrm{mg}$.

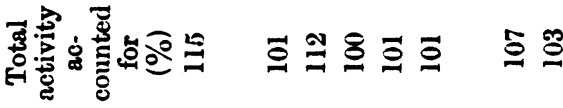

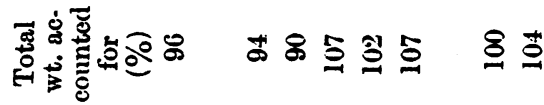

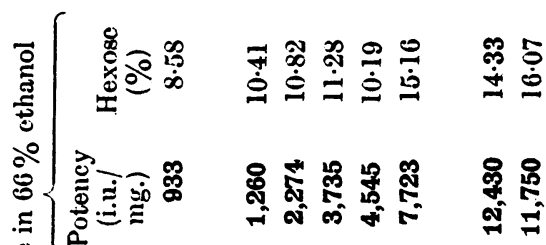

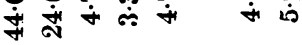

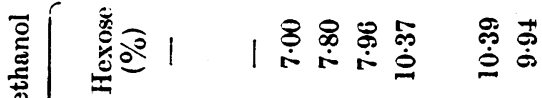
a $\rightarrow$

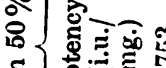
5 :

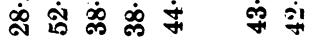
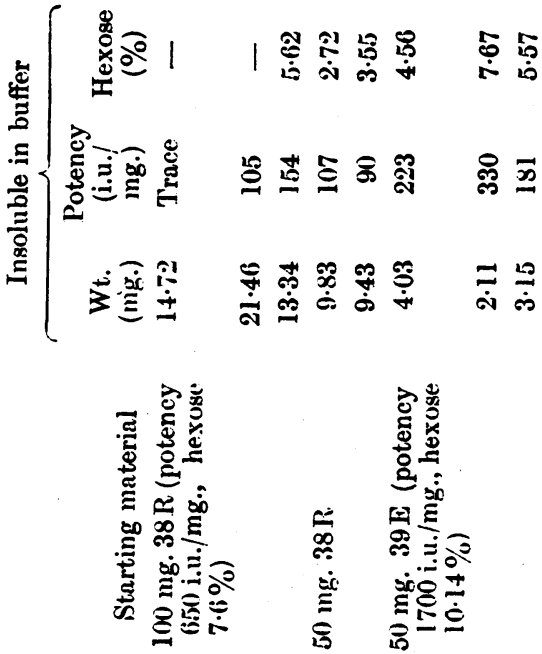

彺

悹苟


lots were employed, and P.M.S. 39E, having potency $1700 \mathrm{i} . u . / \mathrm{mg}$., used in $50 \mathrm{mg}$. lots. The solid was placed in a $15 \mathrm{ml}$. centrifuge tube surrounded by ice, $5 \mathrm{ml}$. of buffer solution at $0^{\circ}$ and a trace of octanol added, the tube stoppered and shaken mechanically for $10 \mathrm{~min}$. The mixture was then centrifuged and the supernatant fluid removed from a small precipitate into another tube, and an equal volume of ethanol added. The mixture was maintained at $0^{\circ}$ for $1 \mathrm{hr}$., centrifuged and the supernatant fluid removed and made up to $66 \%(\nabla / v)$ concentration of ethanol. At this stage it was left overnight at $0^{\circ}$, then centrifuged. The precipitates recovered at each of the three stages were dissolved in appropriate volumes of water (to the first two a drop of dilute ammonium hydroxide being added to effect solution) and analyzed for dry weight of dissolved material, gonadotrophic activity and hexose content. The results are summarized in Table 5. Fig. 1 expresses the relationship between the working $\mathrm{pH}$ and the activity of the resulting product. As stated above, it was not found poesible to employ solutions more acid than pH 1.5, as flocculation in $50 \%$ ethanol did not readily occur under such conditions.

Time of contact with the acid solution. The duration of contact (10 min.) of P.M.S. $39 \mathrm{E}$ with aqueous acid in the preceding experiments was selected arbitrarily. Investigation of the time of contact seemed desirable to discover whether a progressive cleavage of active from inactive material occurred in the acid solution. Experiments were designed in which the substance remained in contact with
$56 \%(\nabla / v)$ ethanol at $\mathrm{pH} 6.5$ and finally fractionation by ethanol at pH 1.5. The product thus obtained weighed only $0.1 \mathrm{mg}$. and contained no gonadotrophic activity. From an equal amount of typical pregnant mares' serum, assaying 150 i.u./ml., a yield of approximately $20 \mathrm{mg}$. of purified material (potency about 10,000 i.u./mg.) would have been expected, even assuming that the over-all recovery of gonadotrophic activity did not exceed $25 \%$. Some details concerning the different fractions are given in Table 7.

It will be noticed that the hexose contents of the various fractions analyzed during this experiment even at the ultimate stage follow very closely those of corresponding fractions obtained from pregnant mares' serum (cf. Tables 1 and 5). It is also of interest, in view of the claim of Cole \& Gose (1939) to have demonstrated the presence of gonadotrophin in the blood of a non-pregnant mare, that the small amount of material appearing in our final fraction was devoid of any gonadotrophic activity. Admittedly, however, the normal sera which were used for our experiment had been in store in a cold room for several weoks.

\section{Ratio of hexose to hexosamine: total carbohydrate content of active fractions}

Potent gonadotrophin preparations are rich in carbohydrate. Gurin (1942) has tabulated data showing that both the pituitary gonadotrophins, follicle-stimulating hormone and luteinizing hor-

\section{Table 6. Fractionation at $\mathrm{pH} 2.5$ after varying periods of contact with the acid solution}

\begin{tabular}{|c|c|c|c|}
\hline \multirow{2}{*}{$\begin{array}{l}\text { Time of } \\
\text { contact } \\
\text { with buffer } \\
\text { pH } \mathbf{2 . 5}\end{array}$} & \multicolumn{3}{|c|}{ Insoluble in $50 \%(v / v)$ ethanol } \\
\hline & $\begin{array}{l}\text { Wt. } \\
\text { (mg.) }\end{array}$ & $\begin{array}{l}\text { Potency } \\
\text { (i.u./mg.) }\end{array}$ & $\begin{array}{c}\text { Hexose } \\
(\%) .\end{array}$ \\
\hline $\begin{array}{l}5 \mathrm{~min} . \\
1 \mathrm{hr} . \\
24 \mathrm{hr} .\end{array}$ & $\begin{array}{l}42 \cdot 40 \\
42 \cdot 70 \\
42 \cdot 44\end{array}$ & $\begin{array}{r}1300 \\
1230 \\
928\end{array}$ & $\begin{array}{l}11 \cdot 17 \\
11 \cdot 71 \\
11 \cdot 22\end{array}$ \\
\hline
\end{tabular}

a phthalate buffer of pH 2.5 for $5 \mathrm{~min}$., $1 \mathrm{hr}$. and $24 \mathrm{hr}$. respectively. The potency of the material precipitated from $66 \%(\nabla / v)$ ethanol was not affected, however, to any marked extent by prolongation of the treatment in acid, as is shown in Table 6, but some loss of total activity took place in the mixture left for $24 \mathrm{hr}$.

Control experiment with normal serum. 5.5 l. of pooled horse serum were put through the process outlined on p. 54, followed by extraction with $50 \%(\nabla / \nabla)$ ethanol containing buffer pH $4 \cdot 8$, removal of material insoluble in

\section{Table 7. Fractions obtained by processing 5.5 1. of normal horse serum}

\section{Fraction}

After titration in $50 \%$ ethanol to pH 4.8

After shaking with $\mathbf{5 0 \%}$ ethanol containing buffer $\mathbf{p H ~ 4 . 8}$

After treating with buffer pH 1.54 and othanol to $50 \%$. Insoluble fraction Supernatant fluid from the above brought to $66 \%$ ethanol. Final fraction

\begin{tabular}{|c|c|c|}
\hline \multicolumn{3}{|c|}{ Insoluble in $66 \%(\nabla / \nabla)$ othanol } \\
\hline $\begin{array}{l}\text { Nt. } \\
\text { ng.) }\end{array}$ & $\begin{array}{l}\text { Potency } \\
\text { (i.u./mg.) }\end{array}$ & $\begin{array}{c}\text { Hexose } \\
(\%)\end{array}$ \\
\hline 472 & $\begin{array}{l}7417 \\
9180 \\
6980\end{array}$ & $\begin{array}{l}13.93 \\
16.76 \\
15.01\end{array}$ \\
\hline
\end{tabular}

$\begin{array}{cc}\begin{array}{c}\text { Total wt. } \\ \text { accounted } \\ \text { for }\end{array} & \begin{array}{c}\text { Total } \\ \text { activity } \\ \text { accounted } \\ \text { for }\end{array} \\ (\%) & (\%) \\ 98 & 111 \\ 95 & 104 \\ 95 & 82\end{array}$

mone, contain hexose (probably mannose) and hexosamine in the proportion $1: 1$, whilst in human urinary and horse serum gonadotrophins this ratio is $2: 1$, the hexose being galactose only or, possibly, equal quantities of galactose and mannose. The ratio of hexose' to hexosamine in the various carbohydrate-containing fractions of normal horse serum, viz. globulins, albumins, seromucoid, has been investigated and found to be $2: 1$ in each case (Rimington, 1931, 1940), the sugars being apparently glucosamine, galactose and mannose. It was thought, therefore, that carbohydrate analyses upon the various fractions obtained during the purification of horse serum gonadotrophin might prove to be of considerable interest. We have already published some such figures (Rimington \& Rowlands, 1941) and pointed out that, at one stage of the purification, the hexose content of the active fraction decreases as its potency is raised. At a later stage, this trend is reversed, showing that relatively less rich glycoprotein impurities are then being eliminated, but during the course of treatment 
with $50 \%$ ethanol at $\mathrm{pH} 1.5$, an increase of from sevenfold to tenfold in potency of the product is accompanied by not more than a $50 \%$ increase in hexose content. Clearly, therefore, hexose content cannot be accepted as a measure of gonadotrophic activity. The above-mentioned facts, taken together with the finding that the trace of material passing through to the end-stage from normal horse serum had about the same hexose content (14.5\%) as our most active fractions, suggest that the active serum gonadotrophin must be only one of several serum glycoproteins of very similar chemical composition; indeed, the question may be raised whether the gonadotrophin is not a chemically modified seroglycoprotein. Determinations of the hexose : hexosamine ratio of purified gonadotrophin specimens (for methods, see Rimington, 1940) show them to resemble the serum proteins in possessing a ratio of $2: 1$, as recorded in Table 8 .

Table 8. Hexose : hexosamine ratio of serum gonadotrophin preparations

$\begin{array}{lcccc} & \begin{array}{c}\text { Potency } \\ \text { Hexos- }\end{array} & \begin{array}{c}\text { Hexose } \\ \text { amine }\end{array} & \begin{array}{c}\text { Hexose } \\ \text { Preparation }\end{array} & \begin{array}{c}\text { hexosamine } \\ \text { (i.u./mg.) }\end{array} \\ \text { (\%) } & \text { ratio } \\ \text { P.M.S. 38E } & \mathbf{3 0 0 0} & \mathbf{5 . 7 9} & \mathbf{1 1 . 2 5} & \mathbf{1 . 9 4} \\ \text { LM 66 } & \mathbf{7 0 0 0} & \mathbf{8 . 4 7} & \mathbf{1 6 . 9 0} & \mathbf{2 . 0 0}\end{array}$

\section{Stability of serum gonadotrophin preparations}

Several different authors have reported upon the stability of gonadotrophin preparations of varying activity. Thus Bischoff (1938), working with a pregnant mares' serum preparation, $0.1 \mathrm{mg}$. of which gave a $200-300 \%$ increase in ovarian. weight (presumably about 100-200 i.u./mg.), found that there was no loss of activity in $24 \mathrm{hr}$. at $\mathrm{pH} 4$ (acetic acid) or pH 10 (sodium borate), whilst Evans \& Hauschildt (1942) report that citrate buffers, $\mathrm{pH}$ $5 \cdot 25-3.63$, caused a decrease in the activity of preparations assaying 800 and 1800 i.u./mg. Li, Evans \& Wonder (1940), working with a preparation containing 1000 of their rat units/mg. (presumably about 4000-5000 i.u./mg.), and which was homogeneous in the Tiselius electrophoresis apparatus, reported that when kept in a desiccator at room temperature fo: 2 weeks, the dry powder lost about $50 \%$ of its activity without change in its electrophoretic homogeneity; after this time, the activity remained constant. No inactivation is stated to have occurred in solutions kept at $1.5^{\circ}$ for 35 days. It was less stable in alkaline solutions than in acid.

It has been our experience that, with regard to retention of their biological activity, the behaviour of our gonadotrophin preparations has been capricious. Fractions kept in neutral solution at $1.5^{\circ}$ have at times shown little change during months; others have rapidly declined in potency in the course of a few weeks. Similarly, our dry preparations, stored at room temperature over $\mathrm{CaCl}_{2}$, have usually declined slowly in potency, although occasional samples have remained unchanged for as long as 6 months. In general, the higher the potency of the specimen, i.e. the more nearly approaching purity, the more rapid has been the loss of activity, but striking exceptions to this generalization have been encountered. We have frequently observed that the loss of activity on storage may approximate to $50 \%$ as reported by $\mathrm{Li}$ et al. (1940), but such a figure may be devoid of real significance, especially if inactivation follows an exponential course, as is to be expected. As yet, we are unable to define all the factors upon which loss of activity depends. We have, however, carried out some experiments which appear to indicate that atmospheric oxygen plays no rôle.

Rates of inactivation of gonadotrophin at $60^{\circ}$ in presence of air, oxygen and nitrogen. A solution was prepared containing $210 \mathrm{i} . u$. $/ \mathrm{ml}$, and $5 \mathrm{ml}$. placed in each of three flasks together with $5 \mathrm{ml}$. of phosphate buffer pH 5.9. The flakks were placed in an incubator at $60^{\circ}$ and oxygen or nitrogen respectively bubbled continuously through two of the mixtures, whilst the third flask, which was stoppered, served as a control. Samples were withdrawn at 24-hourly intervals and assayed. The results (Table 9) show that inactivation proceeded in all three flasks at approximately the same rate.

Table 9. Rate of inactivation of gonadotrophin at $60^{\circ}$ and $\mathrm{pH} 5.9$ in oxygen, nitrogen and air respectively

\begin{tabular}{cccc} 
Time & \multicolumn{3}{c}{ Potency of solution in } \\
\cline { 2 - 4 }$($ hr.) & $\begin{array}{c}\text { Oxygen } \\
(\text { i.u./ml. })\end{array}$ & $\begin{array}{c}\text { Nitrogen } \\
\text { (i.u. } \text { ml. })\end{array}$ & $\begin{array}{c}\text { Air } \\
\text { (i.u./ml. })\end{array}$ \\
0 & 210 & 210 & 210 \\
24 & 113 & 160 & 170 \\
48 & 105 & 127 & 80 \\
72 & 45 & 60 & 43 \\
96 & 31 & 28 & 40
\end{tabular}

Effect of pH upon stability. For these experiments, a preparation was used assaying 1700 i.u./mg. A stock solution was prepared containing $0.1 \mathrm{mg} . / \mathrm{ml}$., and to each $10 \mathrm{ml}$. portion $1 \mathrm{ml}$. of appropriate buffer was added and a drop of chloroform as preservative. The flasks were stoppered, placed in an incubator at $37^{\circ}$, and samples withdrawn for assay at intervals during 10 days. The results are recorded in Table 10. It will be seen that even in water alone fairly rapid inactivation takes place, but, in both acid and alkaline media, this rate is greatly accelerated. The form of the curves of inactivation could not be very accurately determined owing to the limitations of the biological assay method. 
Table 10. Stability of gonadotrophin at various $\mathrm{pH}$ values at $37^{\circ}$

\begin{tabular}{|c|c|c|c|c|c|c|c|c|c|c|c|c|c|}
\hline \multirow[b]{2}{*}{ Buffer } & \multirow[b]{2}{*}{$\mathbf{p H}$} & \multicolumn{12}{|c|}{ Potency (i.u./ml.) after contact with buffer for varying times (days) } \\
\hline & & 0 & $0 \cdot 3$ & 1 & 2 & 3 & 4 & 5 & 6 & т & 8 & 9 & $10^{\circ}$ \\
\hline Acetate & $\begin{array}{l}3.5 \\
4.5 \\
6.5\end{array}$ & $\begin{array}{l}175 \\
175 \\
175\end{array}$ & $\frac{95}{-}$ & $\begin{array}{r}53 \\
103 \\
117\end{array}$ & $\begin{array}{r}19 \\
99 \\
138\end{array}$ & $\begin{array}{r}9 \\
82 \\
\end{array}$ & $\overline{\overline{123}}$ & $\begin{array}{r}\mathbf{3} \\
\mathbf{3 7} \\
\end{array}$ & $=$ & $\begin{array}{r}\overline{58} \\
119\end{array}$ & $\begin{array}{l}\overline{30} \\
97\end{array}$ & 二 & $\begin{array}{r}\overline{29} \\
130\end{array}$ \\
\hline $\begin{array}{l}\text { Water only } \\
\text { Borate }\end{array}$ & $\begin{array}{l}-\overline{7.55} \\
8.0 \\
8.5 \\
9.5\end{array}$ & $\begin{array}{l}175 \\
175 \\
175 \\
175 \\
175\end{array}$ & $\bar{z}$ & $\begin{array}{r}\frac{175}{95} \\
126 \\
131\end{array}$ & $\begin{array}{r}180 \\
120 \\
112 \\
92 \\
55\end{array}$ & $\begin{array}{l}- \\
\mathbf{9 3} \\
\mathbf{5 8} \\
\mathbf{3 5}\end{array}$ & $\begin{array}{r}155 \\
112 \\
68 \\
37 \\
60\end{array}$ & $\frac{\bar{z}}{\overline{56}}$ & $=$ & $\begin{array}{r}123 \\
58 \\
66 \\
-66\end{array}$ & $\begin{array}{l}\bar{z} \\
\bar{z}\end{array}$ & $\begin{array}{l}\text { 二 } \\
\text { 二 }\end{array}$ & $\begin{array}{l}81 \\
47 \\
35 \\
23 \\
43\end{array}$ \\
\hline
\end{tabular}

Attempted reactivation of inactivated material. It was claimed by Bowman (1941) that heat-inactivated chorionic gonadotrophin could be reactivated by treatment with quinol in alkaline solution. In our experience treatment with quinol over the $\mathrm{pH}$ range 7.5-10 of material inactivated by exposure to oxygen, nitrogen or air at $60^{\circ}$ and of acid- or alkaliinactivated material has resulted in no reactivation. Bischoff (1942) has been similarly unable to support Bowman's claim.

The marked and capricious instability of purified gonadotrophin preparations renders experimental work directed towards final purification extremely difficult, especially since physical methods, such as electrophoresis, are unable to distinguish between active and inactivated material ( $\mathrm{Li}$ et al. 1940).

Although the carbohydrate content of our most active preparations tends to be high, we aire quite unable to agree with Li, Evans \& Wonder that "the carbohydrate determination may be taken as a measure of P.M.S. potency in the purification of the hormone'. We believe that the problem is essentially that of separating one or more gonadotrophically active glycoproteins from other inert glycoproteins of approximately similar composition and from hormone which has lost its biological activity.

\section{SUMMARY}

1. Improvements have been made in the method previously published for the preparation of gonado. trophic extracts from pregnant mares' serum.

2. By the improved method, fractions are obtained assaying 200-1000 i.u./mg. and representing a yield of approximately $70 \%$ of the original activity of the serum.

3. Further purification of the product is accom- plished by $(a)$ shaking the dry solid with $50 \%(v / v)$ ethanol containing buffer pH 4.8, (b) removal of material insoluble in $56 \%(v / v)$ ethanol at $\mathrm{pH} 6.5$ and finally (c) fractionation by ethanol at $\mathrm{pH} 1 \cdot 5$. In this manner preparations have been obtained assaying 12,500 i.u./mg. Normal horse serum, similarly treated, yielded only a trace of material devoid of gonadotrophic activity, but containing approximately the same amount of carbohydrate as our most active gonadotrophic preparations. Carbohydrate content is no measure of gonadotrophic activity.

4. The duration of contact of material, as in the ultimate stage, with aqueous acid solution, $\mathrm{pH} 2.5$, does not affect the potency of the resulting product, whence it is concluded that the action of the acid is not a progressive cleavage of inert material from an active moiety such as a prosthetic group.

5. Studies on the stability of active fractions show that: (a) $85 \%$ of their activity is lost by heating at $60^{\circ}$ for $96 \mathrm{hr}$., (b) the rate of inactivation is the same in the presence of air, oxygen or nitrogen, (c) spontaneous inactivation occurs in watery solution at $37^{\circ}$ and more rapidly in the presence of acid or alkaline buffers; the pH range 3.5-9.5 has been studied. Inactivated material could not be reactivated by quinol.

6. The hexose : hexosamine ratio of the purified material was found to be $2: 1$, similar to that of other protein fractions of normal serum. The possible relationship between serum gonadotrophin and other sero-glycoproteins is discussed.

We wish to thank Mr A. W. Hemmings for several suggestions made during the course of his technical assistance. Many of these suggestions have materially contributed tis the efficiency and ease of the process which we describe in this paper for the preparation of serum gonadotrophin.

\section{REFERENCES}

Bischoff, F. (1938). J. biol. Chem. 125, 697.

- (1942). J. biol. Chem. 145, 545.

Bowman, D. (1941). J. biol. Chem. 137, 293.

Cole, H. \& Goss, H. (1939). Amer. J. Physiol. 127, 702.

Evans, J. S. \& Hauschildt, J. D. (1942). J. biol. Chem. $145,335$.

Gurin, S. (1942). Proc. Soc. exp. Biol. Med., N.Y., 49, 48.
Li, C., Evans, H. \& Wonder, D. (1940). J. gen. Physiol. 23, 733.

Rimington, C. (1931). Biochem. J. 25, 1062. (1940). Biochem. J. 34, 931.

_ \& Rowlands, I. W. (1941). Biochem. J. 35, 736.

- (1943). Nature, Lond., $152,355$.

Sevag, M. (1934). Biochem. Z. 273, 419. 